\title{
What the fluff is this? - Gammarus pulex prefer food sources without plastic microfibers
}

Article

Accepted Version

Yardy, L. and Callaghan, A. (2020) What the fluff is this? Gammarus pulex prefer food sources without plastic microfibers. Science of the Total Environment, 715. 136815. ISSN 0048-9697 doi:

https://doi.org/10.1016/j.scitotenv.2020.136815 Available at https://centaur.reading.ac.uk/89509/

It is advisable to refer to the publisher's version if you intend to cite from the work. See Guidance on citing.

To link to this article DOI: http://dx.doi.org/10.1016/j.scitotenv.2020.136815

Publisher: Elsevier

All outputs in CentAUR are protected by Intellectual Property Rights law, including copyright law. Copyright and IPR is retained by the creators or other copyright holders. Terms and conditions for use of this material are defined in the End User Agreement.

www.reading.ac.uk/centaur 
Central Archive at the University of Reading

Reading's research outputs online 
1 What the fluff is this? - Gammarus pulex prefer food sources without 2 plastic microfibers.

3 Lewis Yardy, Amanda Callaghan

4 Ecology and Evolutionary Biology, School of Biological Sciences, University of Reading, 5 Harborne Building, Reading RG6 6AS, UK

6 Microplastics, Microfibres, Pollution, Amphipoda 


\section{Abstract}

8

9 Investigations into the impact of micro plastics (MP) and microfibers (MFs) upon the

10 freshwater aquatic environment are still in their infancy despite our growing awareness of

11 their importance. Gammarus pulex have long been used as a study organism for

12 ecotoxicology and several studies have already used them to investigate the impact of MFs.

13 One area of research which has not been exploited is the extent to which G.pulex can detect

14 MFs and whether or not they avoid eating them. To answer this question we developed a reliable and accurate method of exposing Gammarus to known amounts of MF embedded

16 in algal wafers. Here we show that when given the choice between control wafers and

17 those contaminated with $2 \%$ or $3 \%$ MF Gammarus ingest fewer MF than would be expected

18 if a random choice was made $(2 \% \mathrm{~W}=7 \mathrm{P}=0.01698,3 \% \mathrm{~W}=13 \mathrm{P}=0.03397)$. Their feeding

19 behaviour also changes, with a significant reduction in time feeding $\left(\mathrm{F}_{1,18}=21.3 \mathrm{P}=0.0002\right)$ as well as significantly fewer visits to contaminated wafers $\left(F_{1,18}=5.312 \mathrm{P}=0.0333\right)$. This

21 suggests that G.pulex are able to detect MF in the $200-500 \mu \mathrm{m}$ range and are partially repelled by them. 


\section{Introduction}

Approximately $70 \%$ to $80 \%$ of microplastics (MPs) in marine environments are thought to originate from inland sources and be transported out from rivers to the oceans (Andrady, 2011). Microplastics are defined as diverse plastics, including polyethylene and polystyrene, whose fragments are smaller than $5 \mathrm{~mm}$ in size, they can be particles or fibres, fibres being more than twice as long as they are thick and generally thinner than human hair (Cole, Lindeque, Halsband, \& Galloway, 2011). They can be produced by the degradation of larger particles, for example through clothes washing (Browne et al., 2011; Napper \& Thompson, 2016), or are manufactured as microbeads for use in personal care products including toothpaste, sunscreen and facial scrubs (Duis \& Coors, 2016; Fendall \& Sewell, 2009; Kalčíková, Alič, Skalar, Bundschuh, \& Gotvajn, 2017; Leslie, 2014).

The highest volumes of MP pollution have been found in the Northern Hemisphere at water fronts and in enclosed waters near to urban areas (Cózar et al., 2014; Barnes et al., 2009). As well as accumulation in the environment (Cózar et al., 2014), MPs can accumulate in individuals (Browne et al., 2008) and they have even been found in human stools (Schwabl et al., 2018). Their size results in them being easily ingested by many aquatic organisms at various trophic levels and stages of development, including freshwater invertebrates (Cole et al., 2013; Scherer et al., 2017; Al-Jaibachi et al., 2018a, 2018b,; Aljaibachi and Callaghan, 2018). By entering the food chain MPs can be readily transferred between trophic levels (Chua et al., 2014; Betts, 2008; Farrell and Nelson, 2013; Setälä et al., 2014; Davarpanah and Guilhermino, 2015).

Studies to determine the impact of ingested MPs in smaller invertebrates such as copepods, isopods and zooplankton have concluded that MPs have no detrimental effect following 
47 ingestion, possibly because the MPs were too large to cross the midgut wall and were eliminated in faeces (Cole et al., 2013; Cole, 2015). This was found in the isopod Idotea emarginata (Hämer et al., 2014), cladoceran Daphnia magna (Al-jiabachi and Callaghan, 2017) and dipteran mosquito Culex pipiens (Al-Jaibachi et al., 2018a, 2018b,; Aljaibachi and Callaghan, 2018). In studies using the larger Gammarus fossarum, the impact of MP ingestion varied depending on the type of plastic (Straub et al. 2017). Petroleum-based MPs significantly reduced the assimilation efficiency of MP contaminated food in the long-term, whereas biodegradable plastic did not, although ingestion of both types of plastic led to significantly reduced growth compared to the control (Straub et al. 2017). In other studies, Irregular MP fragments of polyethylene terephthalate (PET) had no negative effects on feeding in Gammarus pulex (Weber et al. 2019).

A meta-analysis on the impact of MP on the aquatic environment revealed that most studies had focussed on particles rather than fibres (Foley, Feiner, Malinich, \& Höök, 2018). Microfibres (MFs) have been investigated in several marine crustaceans, including Sand Hoppers (Orchestia gammarellus), Shore Crabs (Carcinus maenas, Carcinus aestuarii) and Langoustine (Nephrops norvegicus) concluding that MF between 1-5mm were ingested (Piarulli et al., 2019; Watts, Urbina, Corr, Lewis, \& Galloway, 2015; Welden \& Cowie, 2016). Welden \& Cowie (2016) found that the number and length of MF retained in the digestive tract of $N$. norvegicus was related to the gastric mill, an organ used to grind food in the upper gut, larger specimens had larger gaps and so more and larger fibres could pass through the gut and be excreted. They found that the only way for these trapped fibres to be lost was through moulting, where their gut lining and gastric mill was shed. 
Most studies into MF have focussed on the marine environment and have found that the majority of fibres from the deep sea benthos were of cellulose origin $(80 \%)$ with the remainder being polyester or acrylic. Degradation in the ocean is linked to UV action, so that plastic MFs in the deep sea tend to persist for hundreds if not thousands of years (Browne et al., 2011; Sanchez-Vidal, Thompson, Canals, \& De Haan, 2018). As the UV absorbance of freshwater is greater than saltwater, and there is likely to be turbidity, there is likely to be a similar problem in deeper river and lakes (Markager \& Vincent, 2000).

The freshwater shrimp G. pulex has been used as a model organism for investigating a range of topics within ecotoxicology, for example hormonal responses (Gismondi, 2018), metabolic responses (Lebrun, Perret, Geffard, \& Gourlay-Francé, 2012), the effect of pesticides (Auber, Roucaute, Togola, \& Caquet, 2011), and heavy metals (Duddridge \& Wainwright, 1980). Gammarus pulex are especially useful for investigating the impact of MP because of their variable diet (Bloor, 2010, 2011; Kunz, Kienle, \& Gerhardt, 2010). While predominantly shredders feeding on leafy detritus, they will predate several invertebrate taxa as well as feed upon carrion. In addition they are an essential food source for many small fish (Kunz et al., 2010; MacNeil, Dick, \& Elwood, 1999) and represent a vector for plastics to enter the vertebrate food chain. Gammaridae are a diverse family of amphipod crustaceans with representatives in freshwater, brackish and marine environments.

Therefore conclusions drawn from studying them are applicable all over the globe (Costa, Neuparth, Correia, \& Helena Costa, 2005; Kunz et al., 2010).

No recent studies have investigated how MP may affect feeding behaviour and may cause selective feeding in G. pulex, nor have G. pulex been exposed to MF. Previous studies have shown that several macroinvertebrates, including G.pulex, will ingest MP in a variety of 
presentations, from as a suspension that settles on food (Weber, Scherer, Brennholt, Reifferscheid, \& Wagner, 2018).

One difficulty in many studies into MFs has been that they are often studied without being incorporated into food sources and in concentrations well above environmentally relevant levels (Hanvey et al., 2017; Wagner et al., 2014). While some studies have produced a method for exposing invertebrates to a reliable dose of MP alongside plant matter (Straub, Hirsch, \& Burkhardt-Holm, 2017), it is unknown how well they work with MF or larger MPs. It has been shown that algae and grasses provide a vector for MP into taxa not obviously at risk of MP ingestion (Goss, Jaskiel, \& Rotjan, 2018; Gutow, Eckerlebe, Giménez, \& Saborowski, 2016), therefore this relationship must be thoroughly investigated.

In this study we have adapted a method for dosing food with MFs that was originally developed to study plant litter decomposition and invertebrate consumption (Kampfraath nutritional value, as this has not yet been learned by individual organisms. 
Materials and Methods

116

\section{$117 \quad$ G.pulex Collection Site}

The G. pulex were collected from Emm Brook, a tributary of the River Lodden, within Dinton Country Park in Reading, between the points (Decimal Degrees 51.440494, -0.874373 to $51.442274,-0.874359)$. This site was chosen for its good population of $G$. pulex, ease of access and because of its relatively shallow depth of $<90 \mathrm{~cm}$. Animals over $12 \mathrm{~mm}$ in length were collected by kick sampling using a hessian net, placed in plastic bottles filled with stream water and transported to the laboratory. The animals were briefly rinsed with reverse osmosis (RO) water in the laboratory to remove silt and river water and then species confirmed using a key (Eggers et al., 2016) .

In the laboratory G. pulex were placed in $45 \mathrm{~L}$ plastic tanks (150 per tank) containing $40 \mathrm{~L}$ aerated Organisation for Economic Co-operation and Development (OECD) reconstituted wafers (Wafer Algae Eater Fish Food, API).

Microfibre Preparation

Black 100\% acrylic wool (Hayfield Bonus DK product code 5723101001, Hobbycraft, Farnborough) was used to generate MFs. The wool was cut into pieces to generate lengths of $<5 \mathrm{~mm}$ by wrapping a length 5 times around two nails placed into a piece of wood $10 \mathrm{~cm}$ apart to generate ten parallel lengths. The wool was sprayed with RO water until it was saturated and then frozen at $-80^{\circ} \mathrm{C}$ for 1 hour. After an hour the wool was removed and the first and last cm removed using a metal scalpel (Swann-Morton No 11 blade) and then cut 
into $5 \mathrm{~cm}$ lengths which were stored on ice until ready to be used. The wool lengths were further sliced into $<500 \mu \mathrm{m}$ lengths and dried on a hot plate.

\section{Wafer Production}

141 Algae wafers, were ground using a mortar and pestle for 1 min until they were powder and stored in an airtight lidded glass beaker to prevent contamination. To make the wafers, $1 \mathrm{~g}$ of the algae powder was added to $0.5 \mathrm{ml}$ of RO water and mixed to form a paste. The paste was shaped into a flat cake $5 \mathrm{~mm}$ thick and placed on a hot plate at $70^{\circ} \mathrm{C}$ for 2 hours to dry. Test wafers were prepared by adding $0.5 \%, 1 \%, 1.5 \%, 2 \%, 2.5 \%$ and $3 \%$ MF fibres by weight to the powder and then homogenized by grinding for a further $1 \mathrm{~min}$ before adding the RO water.

Once dried each cake was cut up into $0.05 \mathrm{~g}$ wafers with a scalpel and placed in a separate lidded container to prevent contamination. To test the accuracy of this method for exposure of animals to known amounts of fibre, ten of each nominal concentration of test wafer were cut into quarters. Each quarter was crushed with a spatula and placed under a 10x binocular microscope (Optech Microtech) for counting.

\section{$\underline{\text { Execution of Tests }}$}

Eight individual Gammarus $12-20 \mathrm{~mm}$ in length were placed in a $5 \mathrm{~L}$ aquarium filled with aerated $2 \mathrm{~L}$ reconstituted water and starved for $24 \mathrm{~h}$. The Gammarus were then individually placed into an aerated $5 \mathrm{~L}$ aquarium filled with $2 \mathrm{~L}$ reconstituted water along with one $0.05 \mathrm{~g}$ wafer (either control or treatment) and left for 4 hours to feed. After 4 hours each Gammarus was removed from its tank, placed in a $5 \mathrm{ml}$ beaker and killed with $50^{\circ} \mathrm{C}$ water. 
the period, resulting in 10 replicates per treatment. Each day the aquariums were rotated in

161 order to ensure that there was no impact from position.

162 Guts were removed from dead Gammarus under a binocular dissection microscope at 10X

163 magnification. To remove the gut, the telson was removed with a second cut immediately

164 behind the eyes. The gut was then pulled whole from the body using fine point forceps and

165 picked through, counting the number of fibres.

167 Choice experiments were conducted using the same protocol, except each test aquarium had one $0.05 \mathrm{~g}$ control wafer as well as a $0.05 \mathrm{~g}$ test concentration wafer. The amount of time each G.pulex spent feeding on each wafer and the number of visits to each were recorded over four hours, this was referred to as behavioural data.

$\underline{\text { Data Analysis }}$

174 All data analysis was conducted using R and R Studio. Shapiro-Wilkes tests were used to test for normality. The wafer data met the assumptions for normality and Two Way Analyses of

176 Variance were conducted to see if there was any significant difference between wafers or wafer quadrants within each concentration. ANOVA was conducted between the concentrations in order to confirm significant difference in the number of MF between the concentrations. 
The ingestion data met assumptions for normality therefore ANOVA was conducted to identify the relationship between the number of MF ingested and the concentration of MF

182 in wafers.

183 The choice data did not meet the assumptions for normality, therefore Kruskall-Wallis tests were used in place of ANOVAs to investigate MF ingestion between concentrations. It was expected that the number of MF ingested would be half that of the non-choice experiment, however it was found that approximately half G.pulex ingested no MF, these were ignored and Wilcoxon Rank tests were used to investigate the difference between the treatments of choice and no choice of those G.pulex which did ingest MF.

Behaviour data fit the assumptions for normality and so ANOVAs were used to identify the functional response.

\section{$\underline{\text { Wafers }}$}

195 All wafers dried and set as expected and were easily dissected. There was no significant difference in acrylic fibre counts between wafers or wafer quadrants within each concentration (Table S1). significantly different between concentrations $F_{1,118}=14766 P<0.0001$. 


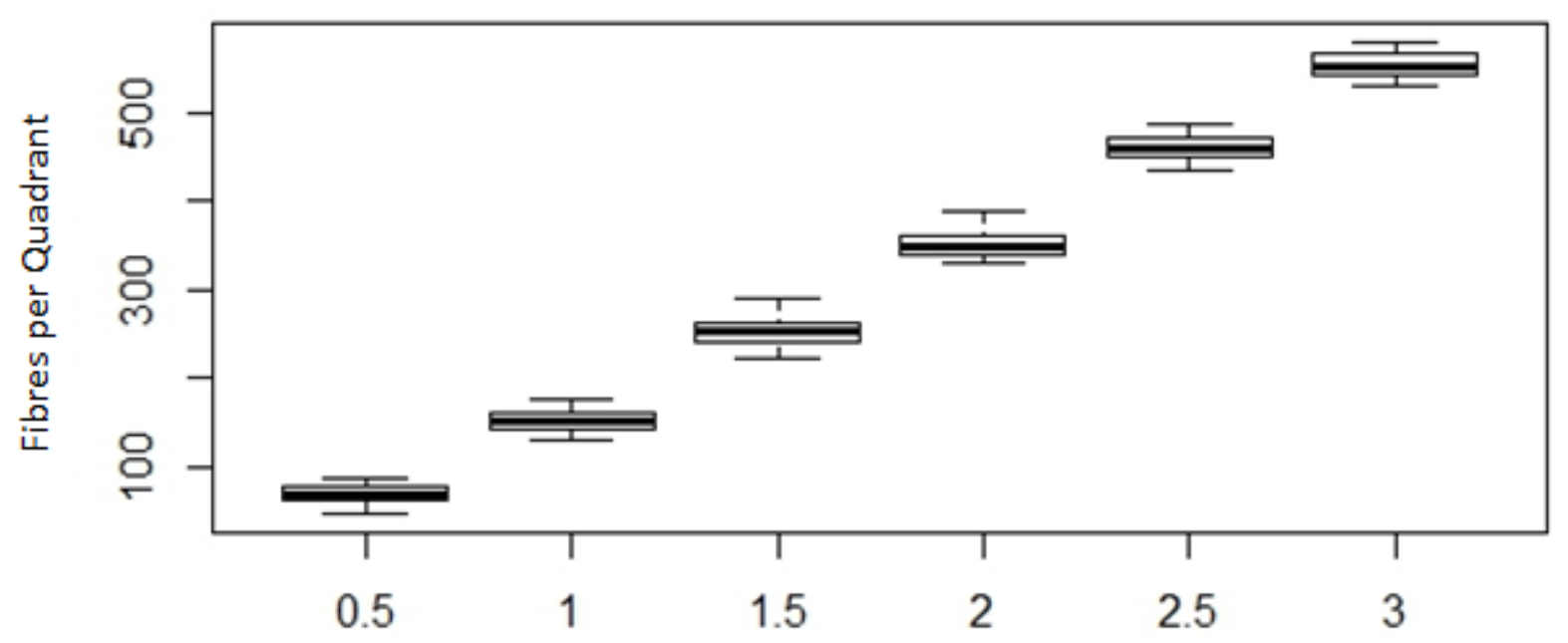

201

Nominal Concentration

Figure 1. The number of fibres per quadrant of algae wafers made using different percentages (by mass) of 200-500 $\mu \mathrm{m}$ Acrylic fibres, $\mathrm{N}$ at each concentration $=40$.

$204 \quad$ Ingestion

205 The G.pulex readily fed on the test wafers and ingested MFs. Thirty percent of the $1 \%$

206 treatment and $10 \%$ of the $2 \%$ treatment ingested no MF. There was a direct relationship

207 between wafer concentration and the number of MF eaten (Fig 2), with a significant

208 difference between test concentrations $F_{1,28}=54.21 P<0.0001$.

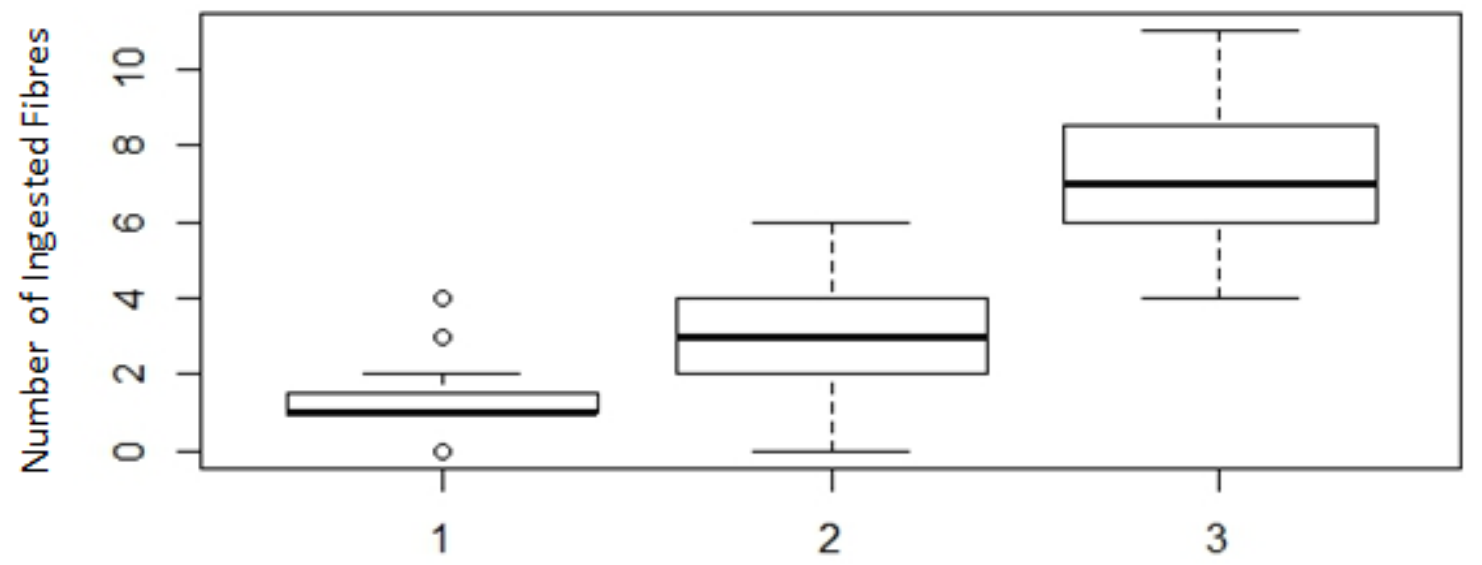

Nominal Concentration 
Figure 2. The number of $200-500 \mu \mathrm{m}$ Acrylic fibres ingested by G.pulex in 4 hours at 3 test concentrations. $\mathbf{N}$

\section{Choice experiments}

213 Gammarus ingestion of MF approximately halved when animals were given a choice

214 between contaminated and uncontaminated food (Fig 3). There was no significant

difference in the number of MFs ingested between the concentrations when given a choice of uncontaminated food $\mathrm{H}(2)=3.028 \mathrm{P}=0.22$. Of the $12 \mathrm{G}$. pulex at each concentration, 4 of the $1 \%, 6$ of the $2 \%$ and 5 of the $3 \%$ had ingested no MF, equating to approximately half of each concentration. When those that had ingested no MF were removed from the data and the remaining results were compared to the no-choice data, those G. pulex with a choice ingested significantly fewer MF than those without a choice Fig $4(2 \% \mathrm{~W}=7 \mathrm{P}=0.017,3 \%$ $W=13 P=0.034)$.

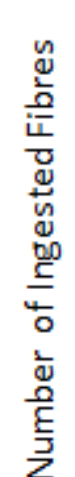

Fig 3. Linear Regressions for the ingestion of 200-500 $\mu \mathrm{m}$ Acrylic fibres by G. pulex, with and without the choice of non-contaminated food. $\mathbf{N}$ for each concentration $=12$. 


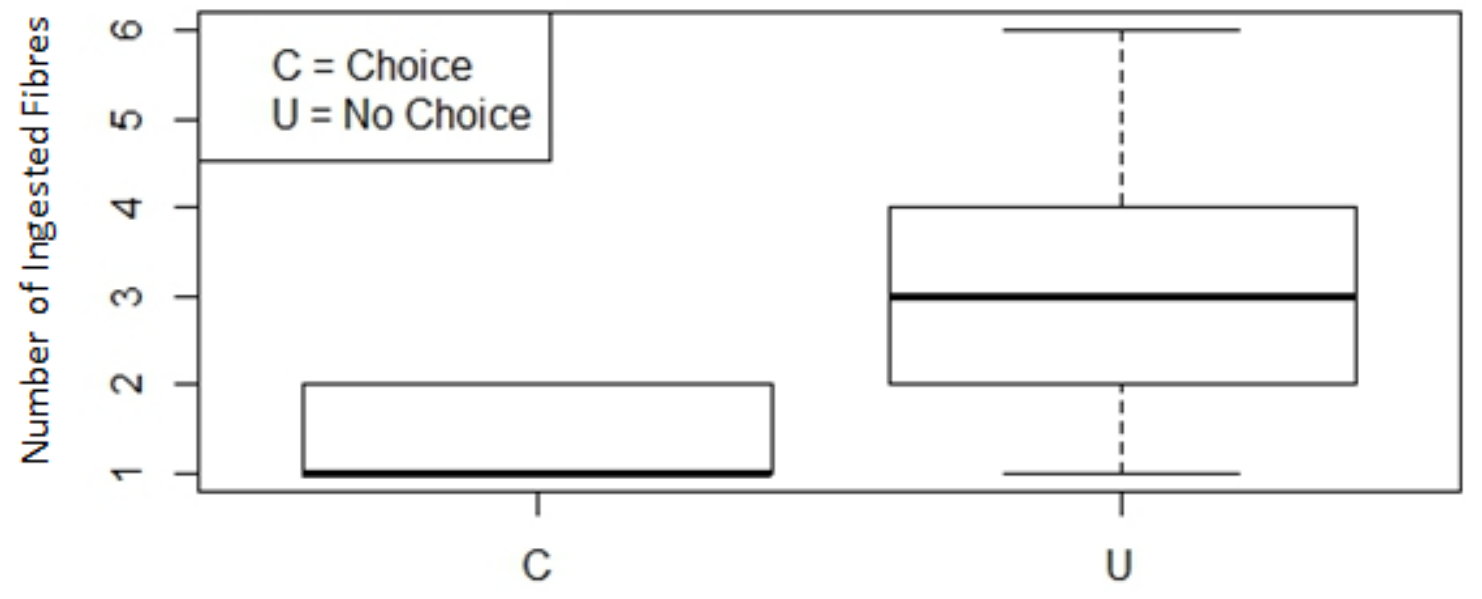

226

Treatment

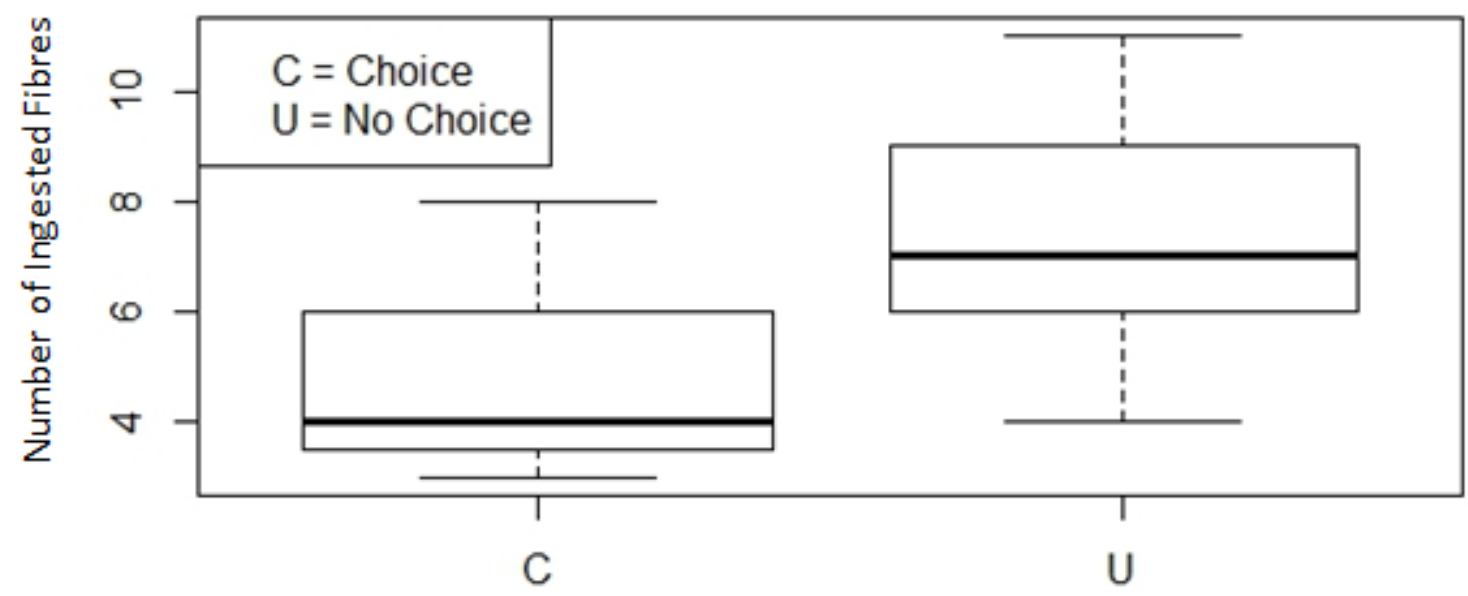

Treatment

Fig 4. The ingestion of $200-500 \mu \mathrm{m}$ Acrylic fibres by G. pulex with and without the choice of uncontaminated food at fibre concentrations (by mass) of $2 \%(A)$ and $3 \%$ (B)

232 The observation tests revealed that $G$. pulex spent significantly less time feeding $\left(F_{1,18}=21.3\right.$ 


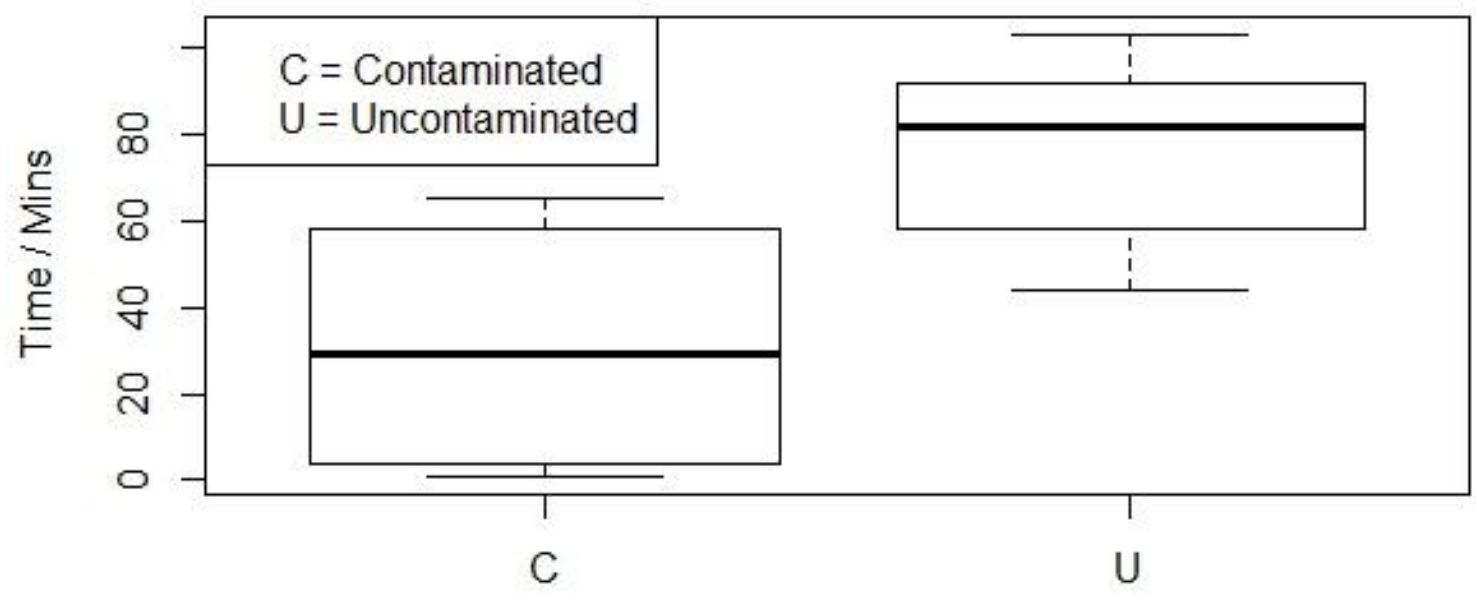

Treatment

236

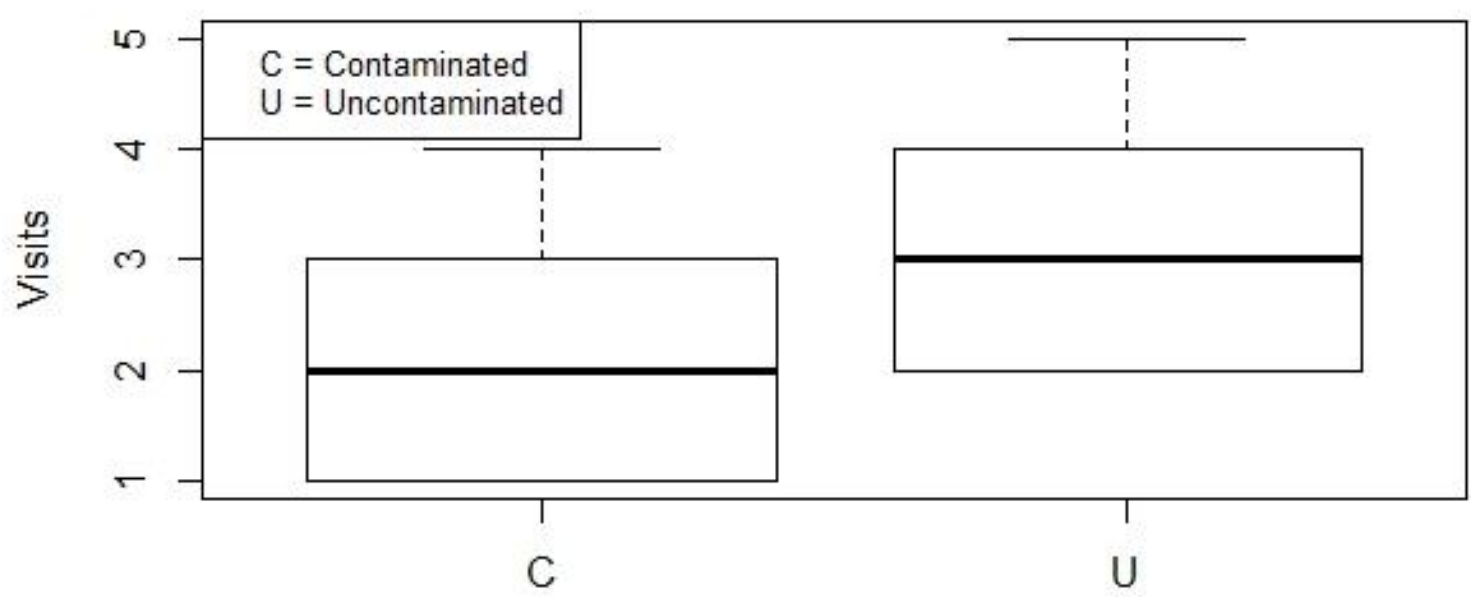

Treatment

Fig 5. The amount of time in minuets G.pulex spend feeding from uncontaminated wafers and wafers contaminated with $200-500 \mu \mathrm{m}$ Acrylic fibres (A) and the number of visits to each type of wafer (B). 
We have developed an accurate, cheap and easy method to produce wafers to investigate the impact of MFs on aquatic invertebrates based on the method of Straub et al., (2017).

The wafers produced were homogenous within a concentration and MF counts were directly proportional to the $\%$ of MF used to produce the wafer. Therefore we can be confident that this method allows reliable dosing of MF which show a tendency to clump together without a solid matrix. G.pulex ingest plastic MFs in lengths up to at least $500 \mu \mathrm{m}$ in proportion to the concentration present.

This method allows researchers to instigate worst case scenarios where invertebrates may be unable to avoid MF and can be used to study preference between different MFs. This method would work for smaller MF and MP, and should be suitable for other organisms which will feed upon algae wafers, enabling a standardised method for understanding the impact of various MPs upon a range of environments.

There are several reasons why invertebrates may detect and avoid plastics in food, there could be chemical cues (De Lange, Sperber, \& Peeters, 2006) or it could be they can physically feel their presence (Carrasco et al., 2019). If the main driving factor is the difference in texture between food and MP then the main food media texture should match the natural food texture as much as possible. An agar based gelatinous food source such as is used by Straub et al., (2017) produces a greater contrast between the food and the MP texture compared to this new method or natural food sources. avoided eating food with MFs, with fewer visits to the food and a reduction in time feeding. 
These observations were supported by quantitative data demonstrating a significant difference in MFs ingested. Gammarus have previously avoided eating contaminated food including when chemical cues to bacteria and fungi are present (De Lange, Lürling, Van Den Borne, \& Peeters, 2005; De Lange, Sperber, \& Peeters, 2006). Furthermore there is evidence that animals can detect and avoid MPs. Carrasco et al( 2019) exposed Orchestoidea tuburculata to artificial food containing $8 \mu \mathrm{m}$ particles of polystyrene MP spheres at 3 different concentrations ( $0 \%, 5 \%$ and $10 \%)$. The animals consumed significantly more food when no MPs were present compared to food contaminated with $10 \%$ MPs. As this study was a relatively short exposure (15 days) it is possible that the avoidance mechanism is physical rather than biochemical. In the current study contaminated wafers were eaten with no evident repulsion when no uncontaminated food was available. This is in line with other studies which have recorded crustaceans, molluscs, annelids and fish, (Farrell \& Nelson, 2013; Foley et al., 2018; Straub et with many studies showing that there is a positive relationship between concentration of MP and the number ingested (Canniff \& Hoang, 2018; Jemec, Horvat, Kunej, Bele, \& Kržan, 2016; Rehse, Kloas, \& Zarfl, 2016). However, Aljaibachi \& Callaghan (2018) found that Daphnia seemed to be able to selectively ingest algal cells and avoid $2 \mu \mathrm{m}$ MP particles. These results are important in understanding the risk to the environment. It suggests that, at least Gammarus is able to avoid MF contaminated food, meaning that as long as their environment is not totally saturated with MF they could be ingested in rates lower than one might assume given environmental concentrations. As macroinvertebrates are the main 
vector for MP entering the higher trophic levels (Foley et al., 2018), including vertebrates and ultimately humans, their ability to limit MP ingestion would in turn limit the amount entering higher trophic levels. (Horton, Walton, Spurgeon, Lahive, \& Svendsen, 2017) and its understanding would help direct mitigation processes.

Gammarus produce copious amounts of faecal pellets which are eaten by other freshwater macroinvertebrates and are important sources of organic matter for bacteria (Joyce, Warren, \& Wotton, 2007). Microfibres were clearly observed in faecal pellets with no evidence of being shortened which means that not only could G.pulex act as a vector for MP to enter higher trophic levels if they are eaten by fish or other invertebrates, but their faeces provide a source of MP to enter lower trophic levels through faecal ingestion (Kelly, Dick, \& Montgomery, 2002; Ladle \& Griffiths, 1980) (Kelly, Dick, \& Montgomery, 2002).

Despite their apparent ability to avoid ingesting MF contaminated wafers, it remains to be seen whether G. pulex predation on differentially contaminated prey would vary. 
Al-Jaibachi, R., Cuthbert, R. N., \& Callaghan, A. (2018a). Examining effects of ontogenic microplastic transference on Culex mosquito mortality and adult weight. Science of The Total Environment, 651, 871-876. https://doi.org/10.1016/j.scitotenv.2018.09.236

Al-Jaibachi, R., Cuthbert, R. N., \& Callaghan, A. (2018b). Up and away: ontogenic transference as a pathway for aerial dispersal of microplastics. Biology Letters, 14(9).

Aljaibachi, R., \& Callaghan, A. (2018a). Impact of polystyrene microplastics on Daphnia magna mortality and reproduction in relation to food availability. PeerJ, 6, e4601. https://doi.org/10.7717/peerj.4601

Aljaibachi, R., \& Callaghan, A. (2018b). Impact of polystyrene microplastics on Daphnia magna mortality and reproduction in relation to food availability. PeerJ, 6, e4601. https://doi.org/10.7717/peerj.4601

Andrady, A. L. (2011). Microplastics in the marine environment. Marine Pollution Bulletin, 62(8), 1596-1605. https://doi.org/10.1016/j.marpolbul.2011.05.030

Auber, A., Roucaute, M., Togola, A., \& Caquet, T. (2011). Structural and functional effects of conventional and low pesticide input crop-protection programs on benthic macroinvertebrate communities in outdoor pond mesocosms. Ecotoxicology, 20(8), 2042-2055. https://doi.org/10.1007/s10646-011-0747-5

Besseling, E., Wang, B., Lürling, M., \& Koelmans, A. a. (2014). Nanoplastic Affects Growth of S. obliquus and Reproduction of D. magna. Environmental Science \& Technology, 48(20), 1233612343. https://doi.org/10.1021/es503001d

Bloor, M. C. (2010). Animal standardisation for mixed species ecotoxicological studies : Establishing a laboratory breeding programme for Gammarus pulex and Asellus aquaticus. Zool. Baetica, 21, 179-190.

Bloor, M. C. (2011). Dietary preference of Gammarus pulex and Asellus aquaticus during a laboratory breeding programme for ecotoxicological studies. International Journal of Zoology. https://doi.org/10.1155/2011/294394

Browne, M. A., Crump, P., Niven, S. J., Teuten, E., Tonkin, A., Galloway, T., \& Thompson, R. (2011). Accumulation of microplastic on shorelines woldwide: sources and sinks. Environmental Science \& Technology, 45(21), 9175-9179. https://doi.org/10.1021/es201811s

Canniff, P. M., \& Hoang, T. C. (2018). Microplastic ingestion by Daphnia magna and its enhancement on algal growth. Science of the Total Environment, 633, 500-507. https://doi.org/10.1016/j.scitotenv.2018.03.176

Carrasco, A., Pulgar, J., Quintanilla-Ahumada, D., Perez-Venegas, D., Quijón, P. A., \& Duarte, C. (2019). The influence of microplastics pollution on the feeding behavior of a prominent sandy beach amphipod, Orchestoidea tuberculata (Nicolet, 1849). Marine Pollution Bulletin, 145, 2327. https://doi.org/10.1016/j.marpolbul.2019.05.018

Cole, M., Lindeque, P., Fileman, E., Halsband, C., Goodhead, R., Moger, J., \& Galloway, T. S. (2013). Microplastic ingestion by zooplankton. Environmental Science and Technology, 47(12), 66466655. https://doi.org/10.1021/es400663f

Cole, M., Lindeque, P., Halsband, C., \& Galloway, T. S. (2011). Microplastics as contaminants in the 
marine environment: A review. Marine Pollution Bulletin. https://doi.org/10.1016/j.marpolbul.2011.09.025

Costa, F. O., Neuparth, T., Correia, A. D., \& Helena Costa, M. (2005). Multi-level assessment of chronic toxicity of estuarine sediments with the amphipod Gammarus locusta: II. Organism and population-level endpoints. Marine Environmental Research, 60, 93-110. https://doi.org/10.1016/j.marenvres.2004.08.005

De Lange, H. J., Lürling, M., Van Den Borne, B., \& Peeters, E. T. H. M. (2005). Attraction of the amphipod Gammarus pulex to water-borne cues of food. Hydrobiologia, 544(1), 19-25. https://doi.org/10.1007/s10750-004-7896-y

De Lange, H. J., Sperber, V., \& Peeters, E. T. H. M. (2006). Avoidance of polycyclic aromatic hydrocarbon-contaminated sediments by the freshwater invertebrates Gammarus pulex and Asellus aquaticus. Environmental Toxicology and Chemistry, 25(2), 452-457. https://doi.org/10.1897/05-413.1

Duddridge, J. E., \& Wainwright, M. (1980). Heavy metal accumulation by aquatic fungi and reduction in viability of Gammarus pulex fed Cd2+ contaminated mycelium. Water Research, 14(11), 1605-1611. https://doi.org/10.1016/0043-1354(80)90065-2

Duis, K., \& Coors, A. (2016). Microplastics in the aquatic and terrestrial environment: sources (with a specific focus on personal care products), fate and effects. Environmental Sciences Europe, 28(1), 2. https://doi.org/10.1186/s12302-015-0069-y

Eggers, T. O., Martens, A., Hanselmann, A. J., Kenna, D., Fincham, W. N. W., Dunn, A. M., ... Pöckl, M. (2016). Bestimmungsschlüssel der Süßwasser-Amphipoda (Crustacea) Deutschlands. Lauterbornia, 42(1), 1-68. https://doi.org/10.1007/s00442-016-3796-x

Farrell, P., \& Nelson, K. (2013). Trophic level transfer of microplastic: Mytilus edulis (L.) to Carcinus maenas (L.). Environmental Pollution, 177, 1-3. https://doi.org/10.1016/j.envpol.2013.01.046

Fendall, L. S., \& Sewell, M. a. (2009). Contributing to marine pollution by washing your face: microplastics in facial cleansers. Marine Pollution Bulletin, 58(8), 1225-1228. https://doi.org/10.1016/j.marpolbul.2009.04.025

Foley, C. J., Feiner, Z. S., Malinich, T. D., \& Höök, T. O. (2018). A meta-analysis of the effects of exposure to microplastics on fish and aquatic invertebrates. Science of the Total Environment. https://doi.org/10.1016/j.scitotenv.2018.03.046

Gismondi, E. (2018). Identification of molt-inhibiting hormone and ecdysteroid receptor cDNA sequences in Gammarus pulex, and variations after endocrine disruptor exposures. Ecotoxicology and Environmental Safety, 158, 9-17. https://doi.org/10.1016/j.ecoenv.2018.04.017

Goss, H., Jaskiel, J., \& Rotjan, R. (2018). Thalassia testudinum as a potential vector for incorporating microplastics into benthic marine food webs. Marine Pollution Bulletin, 135, 1085-1089. https://doi.org/10.1016/j.marpolbul.2018.08.024

Gutow, L., Eckerlebe, A., Giménez, L., \& Saborowski, R. (2016). Experimental Evaluation of Seaweeds as a Vector for Microplastics into Marine Food Webs. Environmental Science and Technology, 50(2), 915-923. https://doi.org/10.1021/acs.est.5b02431

Hanvey, J. S., Lewis, P. J., Lavers, J. L., Crosbie, N. D., Pozo, K., \& Clarke, B. O. (2017). A review of analytical techniques for quantifying microplastics in sediments. Anal. Methods, 9(9), 13691383. https://doi.org/10.1039/C6AY02707E 
Hooper, H. L., Connon, R., Callaghan, A., Maund, S. J., Liess, M., Duquesne, S., ... Sibly, R. M. (2006). The use of image analysis to estimate population growth rate in Daphnia magna. Journal of Applied Ecology, 43(4), 828-834. https://doi.org/10.1111/j.1365-2664.2006.01180.x

Horton, A. A., Walton, A., Spurgeon, D. J., Lahive, E., \& Svendsen, C. (2017). Microplastics in freshwater and terrestrial environments: Evaluating the current understanding to identify the knowledge gaps and future research priorities. Science of the Total Environment. https://doi.org/10.1016/j.scitotenv.2017.01.190

Jemec, A., Horvat, P., Kunej, U., Bele, M., \& Kržan, A. (2016). Uptake and effects of microplastic textile fibers on freshwater crustacean Daphnia magna. Environmental Pollution, 219, 201-209. https://doi.org/10.1016/j.envpol.2016.10.037

Joyce, P., Warren, L. L., \& Wotton, R. S. (2007). Faecal pellets in streams: Their binding, breakdown and utilization. Freshwater Biology, 52(10), 1868-1880. https://doi.org/10.1111/j.13652427.2007.01828.x

Kalčíková, G., Alič, B., Skalar, T., Bundschuh, M., \& Gotvajn, A. Ž. (2017). Wastewater treatment plant effluents as source of cosmetic polyethylene microbeads to freshwater. Chemosphere, 188, 2531. https://doi.org/10.1016/j.chemosphere.2017.08.131

Kelly, D. W., Dick, J. T. A., \& Montgomery, W. I. (2002). The functional role of Gammarus (Crustacea, Amphipoda): Shredders, predators, or both? Hydrobiologia, 485, 199-203. https://doi.org/10.1023/A:1021370405349

Kunz, P. Y., Kienle, C., \& Gerhardt, A. (2010). Gammarus spp. in aquatic ecotoxicology and water quality assessment: Toward integrated multilevel tests. Reviews of Environmental Contamination and Toxicology, 205, 1-76. https://doi.org/10.1007/978-1-4419-5623-1_1

Ladle, M., \& Griffiths, B. S. (1980). A study on the faeces of some chalk stream invertebrates. Hydrobiologia, 74(2), 161-171. https://doi.org/10.1007/BF00014568

Lebrun, J. D., Perret, M., Geffard, A., \& Gourlay-Francé, C. (2012). Modelling copper bioaccumulation in Gammarus pulex and alterations of digestive metabolism. Ecotoxicology, 21(7), 2022-2030. https://doi.org/10.1007/s10646-012-0955-7

Leslie, H. A. IVM Institute for Environmental Studies Review of Microplastics in Cosmetics (2014).

Liu, Z., Yu, P., Cai, M., Wu, D., Zhang, M., \& Huang, Y. (2019). Polystyrene nanoplastic exposure induces immobilization, reproduction, and stress defense in the freshwater cladoceran Daphnia pulex. Chemosphere, 215, 74-81. https://doi.org/10.1016/j.chemosphere.2018.09.176

MacNeil, C., Dick, J. T. A., \& Elwood, R. W. (1999). The dynamics of predation on Gammarus spp. (Crustacea: Amphipoda). Biological Reviews, 74, 375-395. https://doi.org/doi:10.1017/\$0006323199005368

Markager, S., \& Vincent, W. F. (2000). Spectral light attenuation and the absorption of UV and blue light in natural waters. Limnology and Oceanography, 45(3), 642-650. https://doi.org/10.4319/lo.2000.45.3.0642

Napper, I. E., \& Thompson, R. C. (2016). Release of synthetic microplastic plastic fibres from domestic washing machines: Effects of fabric type and washing conditions. Marine Pollution Bulletin, 112(1-2), 39-45. https://doi.org/10.1016/j.marpolbul.2016.09.025

Piarulli, S., Scapinello, S., Comandini, P., Magnusson, K., Granberg, M., Wong, J. X. W., ... Airoldi, L. (2019). Microplastic in wild populations of the omnivorous crab Carcinus aestuarii: A review and a regional-scale test of extraction methods, including microfibres. Environmental Pollution, 


\section{1}

Rehse, S., Kloas, W., \& Zarfl, C. (2016). Short-term exposure with high concentrations of pristine microplastic particles leads to immobilisation of Daphnia magna. Chemosphere, 153, 91-99. https://doi.org/10.1016/j.chemosphere.2016.02.133

Sanchez-Vidal, A., Thompson, R. C., Canals, M., \& De Haan, W. P. (2018). The imprint of microfibres in Southern European deep seas. PLOS ONE, 13(11). https://doi.org/10.1371/journal.pone.0207033

Scherer, C., Brennholt, N., Reifferscheid, G., \& Wagner, M. (2017). Feeding type and development drive the ingestion of microplastics by freshwater invertebrates. Scientific Reports, 7(1). https://doi.org/10.1038/s41598-017-17191-7

Schwabl, P., Liebmann, B., Köppel, S., Königshofer, P., Bucsics, T., Trauner, M., \& Reiberger, T. (2018). Assessment of microplastic concentrations in human stool - Preliminary results of a prospective study. Assessment of Microplastic Concentrations in Human Stool - Preliminary Results of a Prospective Study.

Straub, S., Hirsch, P. E., \& Burkhardt-Holm, P. (2017). Biodegradable and petroleum-based microplastics do not differ in their ingestion and excretion but in their biological effects in a freshwater invertebrate Gammarus fossarum. International Journal of Environmental Research and Public Health, 14(7). https://doi.org/10.3390/ijerph14070774

Wagner, M., Scherer, C., Alvarez-Muñoz, D., Brennholt, N., Bourrain, X., Buchinger, S., ... Reifferscheid, G. (2014). Microplastics in freshwater ecosystems: what we know and what we need to know. Environmental Sciences Europe, 26(1), 1-9. https://doi.org/10.1186/s12302014-0012-7

Watts, A. J. R., Urbina, M. A., Corr, S., Lewis, C., \& Galloway, T. S. (2015). Ingestion of Plastic Microfibers by the Crab Carcinus maenas and Its Effect on Food Consumption and Energy Balance. Environmental Science and Technology, 49(24), 14597-14604. https://doi.org/10.1021/acs.est.5b04026

Weber, A., Scherer, C., Brennholt, N., Reifferscheid, G., \& Wagner, M. (2018). PET microplastics do not negatively affect the survival, development, metabolism and feeding activity of the freshwater invertebrate Gammarus pulex. Environmental Pollution, 234, 181-189. https://doi.org/10.1016/j.envpol.2017.11.014

Welden, N. A. C., \& Cowie, P. R. (2016). Environment and gut morphology influence microplastic retention in langoustine, Nephrops norvegicus. Environmental Pollution, 214, 859-865. https://doi.org/10.1016/j.envpol.2016.03.067 